\title{
Wetland Vegetation Response to Groundwater Pumping and Hydrologic Recovery
}

\author{
Megan K. Bartholomew ${ }^{1} \cdot$ Christopher J. Anderson ${ }^{1}$ (i) - Jacob F. Berkowitz ${ }^{2}$
}

Received: 17 January 2020 / Accepted: 18 September 2020 / Published online: 10 October 2020

(C) The Author(s) 2020

\begin{abstract}
An investigation of wetland vegetation response to groundwater alteration was conducted at the J.B. Starkey Wilderness Park, a large municipal wellfield in the area of west Florida, USA. Decades of historic groundwater withdrawal had created a gradient of impacted wetlands on the wellfield, after which time the groundwater pumping rates were reduced. Nineteen cypress dome wetlands were grouped, based on their hydrologic histories, as either most-altered (least inundation), marginally-altered (intermediate inundation), or least-altered (near-normal inundation). Annual species-level monitoring data were used to evaluate understory plant community response to the hydrologic recovery that resulted from reduced groundwater pumping. Species richness, cover, prevalence index (PI), and species importance percentages were assessed during pre- (2005-2007) and post(2012-2014) hydrologic recovery periods. The vegetation in marginally- and most-altered wetlands responded to hydrologic recovery with increased species richness and lower PI values (i.e., greater hydrophytic character). However, species importance percentages indicated greater variation in the recovery of most-altered wetlands, where species composition often remained different from least-altered wetlands. Although reductions in groundwater pumping caused sufficient passive hydrologic recovery to elicit a vegetation response, further reductions and/or more time may be needed before the vegetation of some altered wetlands can become comparable to that of least-impacted wetlands.
\end{abstract}

Keywords Cypress dome wetlands $\cdot$ Hydrologic recovery $\cdot$ Passive restoration $\cdot$ Groundwater pumping

\section{Introduction}

Hydroperiod (i.e., inundation frequency, duration and level) controls many wetland processes and is pivotal to wetland character in part because of its influences on plant community composition (Battaglia and Collins 2006). Hydroperiod is also focal to wetland restoration efforts and a key consideration when attempting to establish pre-impact or target vegetation assemblages (Kentula 2000; De Steven and Gramling 2013). However restoration efforts may fall short when restored hydrologic regimes are insufficient to support target assemblages (Erwin 1991; Caldwell et al. 2011). Rapid changes in hydroperiod have been shown to result

Christopher J. Anderson

andercj@auburn.edu

1 Auburn University School of Forestry and Wildlife Science, 602 Duncan Drive, Auburn, AL 36849, USA

2 U.S. Army Engineer Research and Development Center, 3909 Halls Ferry Road, Vicksburg, MS 39180, USA in the colonization and spread of undesirable (invasive, inappropriate, and/or monotypic) species, while more gradual changes may allow communities to adapt and adjust over time (Howard and Wells 2009; Froend and Sommer 2010; Palanisamy and Chui 2013). The eventual trajectory of vegetation response to restoration is often uncertain; the pace can vary from years to decades (Matthews et al. 2009; Bortolotti et al. 2016), and may not be adequately detected during the relatively short $(<5$ years $)$ monitoring periods commonly associated with restoration projects (Mitsch and Wilson 1996). A recent meta-analysis of restored wetlands (Moreno-Mateos et al. 2012) indicated that vegetative structure and biogeochemical functioning are commonly deficient compared to reference wetlands and that many restoration trajectories are either very slow or moving toward an alternative state.

Passive (unassisted) vegetation restoration normally relies on natural regeneration for ecological recovery. In wetlands, this can allow for ecological self-design in response to hydrologic restoration (Mitsch and Wilson 1996) and has been advocated in part because it is less expensive, requires lower maintenance, and has a greater potential to sustain natural 
processes compared to more intensive approaches (National Research Council 2001; Halle 2007). Passive restoration has been demonstrated as feasible for wetlands in the southeast U.S. (De Steven et al. 2006, 2010) but has failed to develop characteristic vegetation in other wetland systems such as the Prairie Pothole Region (van der Valk 1981; Galatowitsch and van der Valk 1996). Returning wetland hydroperiods that support characteristic species is especially relevant in depressional, geographically-isolated wetlands of the southeastern USA Coastal Plain. Their distinctive plant communities are influenced by rainfall-driven, seasonal hydroperiods and local geomorphology (Battaglia and Collins 2006; Kirkman et al. 2012). Depressional wetlands are often degraded through ditching and drainage however, in some areas of the Coastal Plain, these wetlands are impacted by groundwater withdrawals that reduce the frequency and duration of inundation, leading to invasion by upland and other uncharacteristic species and eventually to plant community replacement (Kirkman et al. 2000; Florida Natural Areas Inventory 2006). While blocking drainage ditches is a common approach to restoring wetlands, there is less information regarding wetland recovery resulting from reduced groundwater pumping. Because groundwater alterations occur over wider spatial scales than the ditching of single depressional wetlands, restoration can be more challenging and less predictable.

In the Tampa Bay region of west Florida, USA cypress domes (a forested, depressional wetland type) are common and susceptible to degradation caused by groundwater withdrawals from shallow regional aquifers (Pittman and Waite 2009). Until the late-1990s, groundwater pumping from 11 wellfields was used to meet municipal water demands. Long-term groundwater withdrawal lowered the water table in and around these wellfields and caused negative wetland impacts such as shortened hydroperiods, increased upland/invasive species, soil subsidence, tree mortality, and loss of wetland dependent wildlife (Dooris et al. 1990; Rochow 1998; Lee et al. 2009). Due in part to concerns over wetland degradation, alternative municipal water sources were identified, and in the mid-2000s the volume of groundwater pumping was substantially reduced (Southwest Florida Water Management District 2009; Asefa et al. 2014). Since then, wetlands within the wellfields have experienced varying degrees of hydrologic recovery (Metz 2011). Utilizing extensive monitoring data, the purpose of our study was to evaluate the understory vegetation response to hydrologic recovery in wellfield cypress domes. Comparing data before and after reductions in groundwater withdrawal, we evaluated vegetation change over a 5-7 year post-recovery period in 19 wetlands representing a range of past degradation. Understory plant community measures were used to address two primary questions: (1) were there detectable responses to passive hydrologic recovery? and (2) were more-altered wetlands transitioning toward the plant community assemblages observed in wetlands with less hydrologic alteration?

\section{Methods}

\section{Study Site and Wetlands}

Our study was conducted at the J.B. Starkey Wilderness Park (SWP), a 3200-ha wellfield located in New Port Richey, in the northern Tampa Bay region of Pasco County in west Florida, USA (Fig. 1). The SWP includes a variety of upland and wetland ecosystems including moist-soil pine flatwoods, xeric sandhills, and various types of wetlands (Rochow 1998). The climate in the region is considered subtropical and characterized by warm, wet summers and relatively mild, dry winters and springs. Mean annual precipitation in nearby Tampa is $118 \mathrm{~cm} \mathrm{year}^{-1}$ (for 1981-2010; Florida Climate Center 2018). The SWP has historically been used as a groundwater wellfield for the northern Tampa Bay area. The park has 14 wells that began pumping groundwater in the mid-1970s. At first, pumping was moderate ( 4 to 23 million $\mathrm{L} \mathrm{day}^{-1}$ ) and focused in the western portion of the park. However, as regional population increased, pumping steadily increased and expanded to meet demand, first in the central section of the park and then in the eastern section (Fig. 1). Pumping rates reached a peak of 49 million $\mathrm{L} \mathrm{day}^{-1}$ by the mid-2000s (Metz 2011). As the environmental damage from prolonged groundwater withdrawal became apparent, local government and water management agencies worked to reduce groundwater extraction. In 2008, alternative water sources were secured which allowed pumping within SWP to be reduced to 15 million $\mathrm{L}$ day ${ }^{-1}$. The decrease allowed for greater recharge of the surface aquifer and partial restoration of wetland hydroperiod (Tampa Bay Water 2009; Lewis and Feit 2015).

The SWP contains numerous cypress domes, a forested depression type that is common in Florida. These wetlands often exhibit internal zonation of vegetation due to seasonal inundation patterns (Haag et al. 2005). They typically vary in size from 1 to 10 ha (Dierberg and Brezonik 1984) and naturally occur within an upland matrix of slash pine (Pinus elliottii) flatwoods (Marios and Ewel 1983). Both precipitation and shallow groundwater control their hydrology, which makes them especially susceptible to alteration by groundwater extraction. In the SWP, cypress domes are generally dominated by an overstory of pond cypress (Taxodium ascendens) with varying amounts of swamp gum (Nyssa biflora) and other hardwoods. The understories of intact, unaltered cypress domes are diverse across peninsular Florida but often contain ferns such as swamp fern (Blechnum serrulatum), cinnamon fern (Osmunda cinnamomea), royal fern (Osmunda regalis) and Virginia chain fern (Woodwardia virginica) (Noble et al. 2004). Other common understory species include several woody species (buttonbush [Cephalanthus occidentalis], wax myrtle [Myrica cerifera], red maple [Acer rubrum]) and herbaceous species (soft rush [Juncus effusus], denseflower knotweed [Polygonum densiflorum], bladderworts 


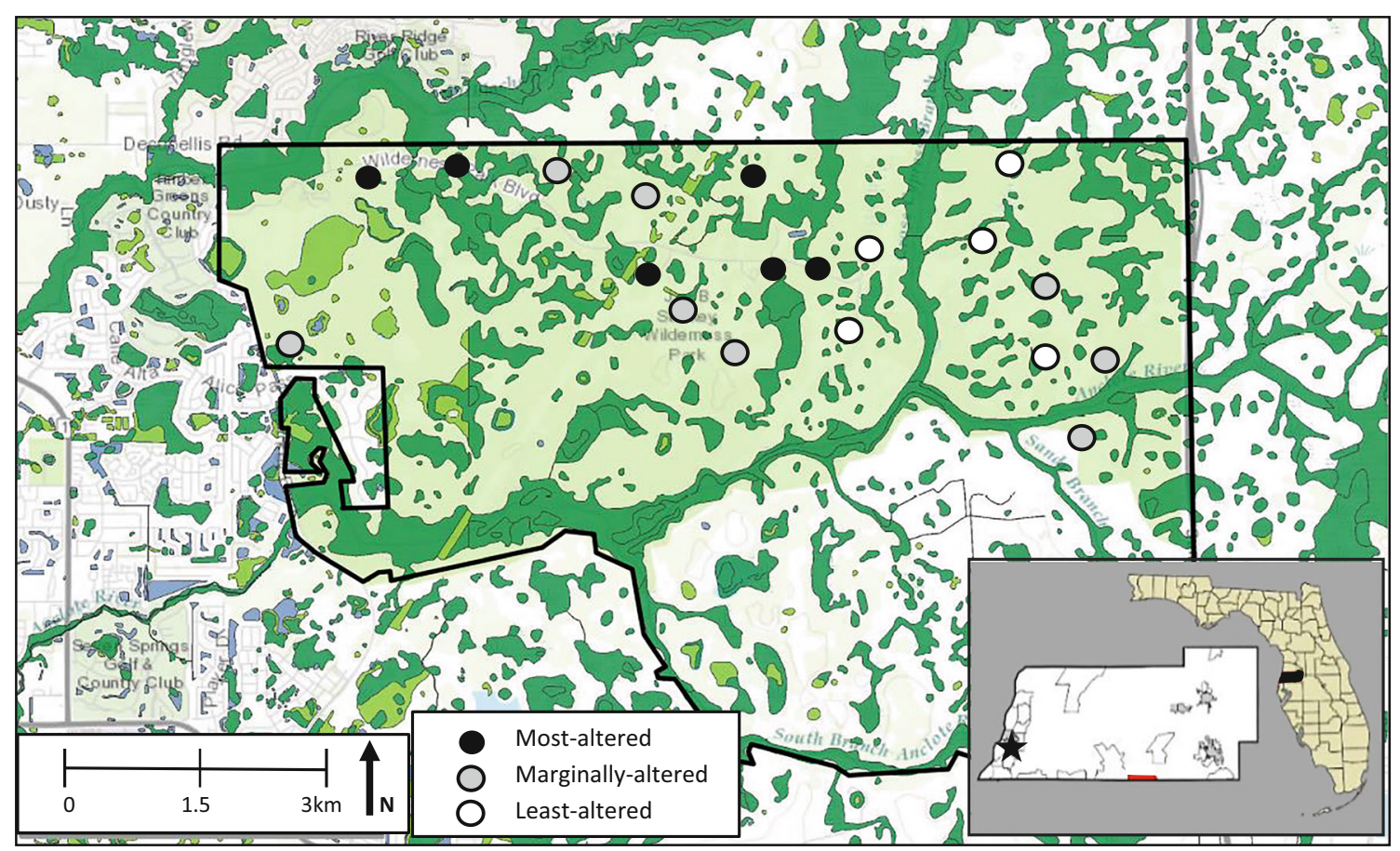

Fig. 1 National Wetland Inventory and location map of the J.B. Starkey Wilderness Park (SWP). Bold line denotes park boundaries and circles represent the wetlands examined in the current study. Inset on bottom right highlights the location of the SWP in Pasco County, FL

[Utricularia spp.]). At the SWP, upland soils surrounding the study wetlands consist of fine sands typical of pine flatwoods (Smyrna, Myakka and Pomona series), while wetland soils are dominated by Sellers mucky fine sands (Stankey 1982).

\section{Hydrologic Monitoring}

Over 80 cypress dome wetlands within the SWP wellfield have experienced various degrees of alteration due to groundwater extraction (Metz 2011). As part of long-term monitoring by the Southwest Florida Water Management District (SWFWMD) and Tampa Bay Water (TBW), permanent staff gauges and groundwater wells have been used to monitor wetland hydrology for the last four decades (SWFWMD and TBW 2005). Using those datasets, we selected 19 cypress dome wetlands for investigation (Fig. 1). Selected sites had hydrologic data collected monthly from 1990 to 1993, then biweekly starting in 1994. Based on these data, two hydrologic periods were designated: a pre-recovery period from 2005 to 2007 (just before groundwater extraction rates peaked, Metz 2011), and a post-recovery period from 2012 to 2014 (5 to 7 years after groundwater extraction was substantially reduced, and after the end of a regional drought in 2006-2008).

For monitoring purposes, SWFWMD and TBW (2005) previously identified and marked three wetland zones (deep, outer-deep, and transition) based on ground elevations relative to historic normal pools (defined as the long-term average water level prior to hydrologic alterations). Historic normal pool levels were established in each wetland based on biological and physical indicators such as tree buttressing, moss collars, and the elevation of fringing saw palmetto (Serenoa repens) (SWFWMD and TBW 2005). Interior depths of Florida cypress domes can vary with some containing near permanently ponded water up to $1 \mathrm{~m}$ deep (Monk and Brown 1965), although subsidence from can deepen them further. This paper examined the outer-deep zone of the studied wetlands, which spans from 15 to $30 \mathrm{~cm}$ below the historic normal pool level (SWFWMD and TBW 2005). Although other zones were analyzed (Bartholomew 2017), we focused on the outer-deep zone because it represents a substantial portion of the entire wetland and is a zone where species assemblage would be more affected by changes in hydroperiod compared to the interior deep zone.

Unaltered cypress domes are typically inundated $>180$ days most years (Casey and Ewel 1998). Therefore, the severity of hydrologic alteration to each wetland was determined based on the average annual days inundated over a 15-year impact period (1990-2005) and the frequency of inundation $>180$ days each year (from 1990 to 2014) before and after groundwater pumping was reduced in 2008. The wetlands were then classed into three hydrologic groups (most-altered, marginally-altered, and least-altered) based on distinct differences in these data (Table 1). Least-altered wetlands $(n=5)$ exhibited an average yearly inundation $>180$ days in their outer-deep zone and were considered most similar to unimpacted reference wetlands. Marginally-altered wetlands $(n=8)$ averaged between 80 and 180 days of inundation per year, while most-altered wetlands $(n=6)$ averaged $<80$ days 
Table 1 Average inundation period for wetlands (1990-2014) and the annual frequency at which inundation exceeded $>180$ days per year before (1990-2007) and after (2008-2014) hydrologic recovery

\begin{tabular}{lrrrr}
\hline Hydrologic Group & $n$ & Average Inundation Period (days per year) & \multicolumn{2}{l}{$\begin{array}{l}\text { Frequency of Annual Inundation } \\
\text { Exceeding 180 days }\end{array}$} \\
\cline { 4 - 5 } \cline { 3 - 4 } & & & $1990-2007$ & $2008-2014$ \\
\hline Least-altered & 5 & $>180$ & $60 \%$ & $60 \%$ \\
Moderately-altered & 8 & $80-180$ & $30 \%$ & $45 \%$ \\
Most-altered & 6 & $<80$ & $2 \%$ & $15 \%$ \\
\hline
\end{tabular}

per year (Table 1). Mean wetland size were $1.1 \pm 0.4$ ha for most-altered wetlands, $2.1 \pm 0.8$ for marginally-altered wetlands, and $3.8 \pm 0.9$ ha for least-altered wetlands. Prior to hydrologic recovery, there was clear separation in hydroperiods between hydrologic groups (Fig. 2). However, the end of the pre-recovery period (2007) also coincided with a severe drought (2006-2008) that affected hydroperiods of all wetlands (Fig. 2). Excessively dry years (e.g., 1999 and 2007) caused durations to be similar among groups; however, the more-altered wetlands eventually responded with increased inundation durations by the later post-recovery period (2012-2014) (Table 1, Fig. 2).

\section{Vegetation Data and Analyses}

For evaluation and monitoring, the SWFWMD and TBW developed the Wetland Assessment Procedure (WAP) (SWFWMD and TBW 2005), which uses annual vegetation surveys (2005 to present) to characterize the condition and function of cypress dome wetlands and document changes in species composition. Understory plants are emphasized because they are considered most responsive to changes in hydrology (Young et al. 1995; Chapin and Page 2013). Understory vegetation in the interior zone of cypress domes can be sparse due to deeper inundation and canopy shading, but shrubs and herbaceous species become more prevalent closer to the wetland periphery (Kirkman et al. 2012).

The WAP vegetation surveys utilized permanently marked plots (one per wetland) that are $10 \mathrm{~m}$ wide and extend perpendicular (down gradient) towards the center of the wetland (i.e., a belt transect, typically 10-20 m long). All groundcover species (defined as all herbaceous plants, and woody species less than $1 \mathrm{~m}$ tall) within the plots were identified to species (or to lowest taxonomic level defined by WAP) and their percent covers determined using visual estimation. For our analyses, we omitted taxa that were not reported to species level (representing $<4 \%$ of all data). Any percent cover that was reported as $<5 \%$ was converted to a median $2.5 \%$. Vegetation surveys were conducted by three or four experienced environmental professionals with extensive botanical experience and who had undergone WAP training in plant identification (C. Shea, personal communication). All surveys were conducted in May or June of the respective year. We used these annual data to calculate several metrics for comparing understory communities over the two hydrologic periods (pre- and post-hydrologic recovery) and among wetland hydrologic groups (most-, marginally-, and least-altered).

Species Richness, Cover, and Prevalence Index Species richness and cover were determined for the outer-deep zone of each wetland as reported in annual WAP reports. Cumulative species
Fig. 2 Mean ( \pm SE) annual percent of year inundated for wetlands in each hydrologic group. Dashed line indicates the initiation of hydrologic recovery

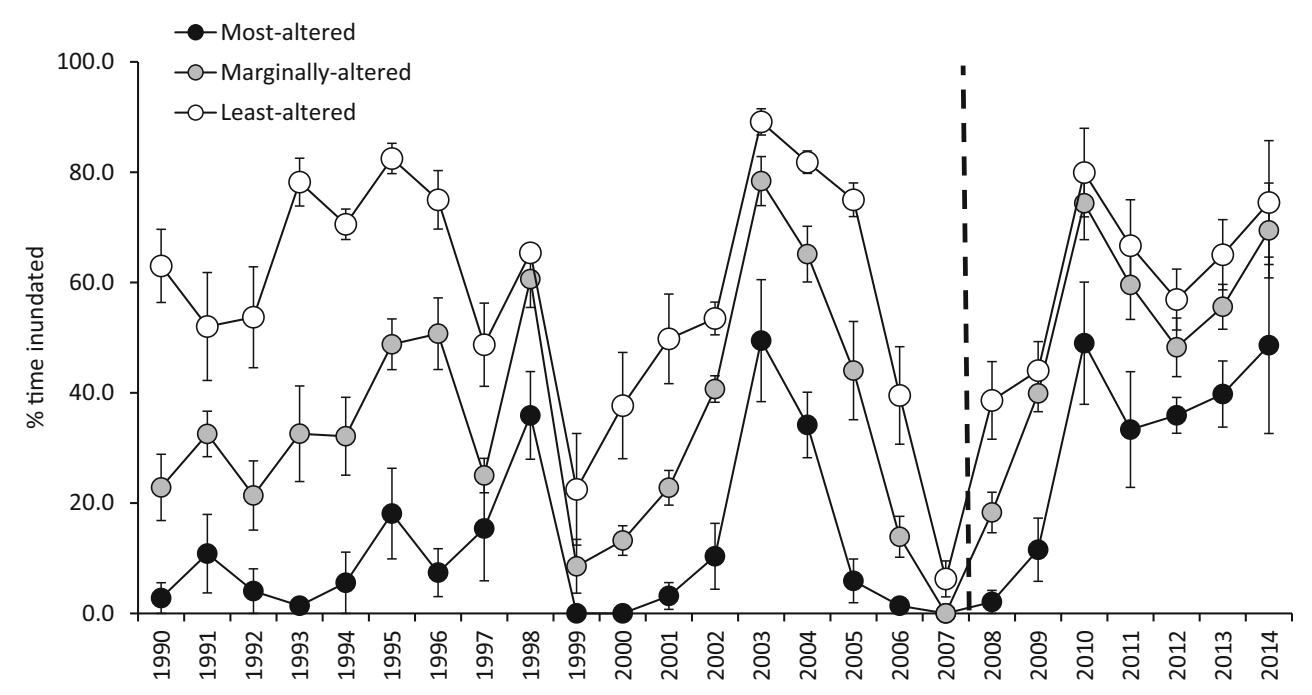


richness and plant cover from these measures were averaged per year for each hydrologic group during the pre- and postrecovery periods.

The composition and hydrophytic character of understory vegetation was described using the prevalence index (PI), which is a cover-weighted average of scores that indicate species affinity to wetland conditions (Wentworth and Johnson 1986). All plant species have one of five hydrophytic plant National Wetland Indicator (NWI) ratings (obligate wetland $[\mathrm{OBL}]$, facultative wetland [FACW], facultative [FAC], facultative upland [FACU], and upland [UPL]; Reed 1988; Lichvar et al. 2016), which were scored as follows: OBL = $1, \mathrm{FACW}=2, \mathrm{FAC}=3, \mathrm{FACU}=4$ and $\mathrm{UPL}=5$. The PI was then calculated as:

\section{Prevalence Index $=\sum^{A_{i}} \mathrm{~W} / \Sigma A_{i}$}

where $A_{i}=$ cover of species $i$ and $W_{i}=$ wetland indicator score for species $i$.

Lower species scores indicate a greater affinity to wet habitats, and PI values of $\leq 3$ are defined as indicative of a hydrophytic plant community (USACE 2012). Annual PI scores were averaged for each hydrologic group and compared between pre- and post-recovery periods.

Repeated measures analysis of variance (ANOVA) was used to test for differences in the vegetation variables between hydrologic groups, pre- and post-recovery periods, and for potential interactions. Post-hoc comparisons between groups were conducted using Tukey's honest significant difference (HSD) test. In instances where the assumption of normality was violated (e.g., species richness), data were natural-log transformed to improve distributions prior to analysis. All statistical analyses were run in Minitab 18, with a significance level of $\alpha=0.05$.

WAP Category Proportions The WAP recognizes 111 plant species that are characteristic of cypress dome wetlands and considered sensitive to hydrologic alteration (SWFWMD and TBW 2005). Each WAP-listed species is classified as either Upland, Adaptive, Transition, Outer-Deep, or Deep, based on the habitat zone it typically occupies and its wetland indicator rating as established by the State of Florida (Chapter 62-340, Florida Administrative Code) (see Table 2). For our analyses, we consolidated all species into one of three categories. Species that were WAP-listed and characteristic of the cypress dome interior (i.e., Transition, Outer-Deep and Deep) were designated 'WAP wetland'. Species typically upland or ruderal (i.e., Upland or Adaptive) in cypress domes were designated 'WAP upland/adaptive'. We defined a third 'Non-WAP wetland' category for any species that was not designated as a WAP species. Although non-WAP species can be upland to wetland obligate (Table 2), the vast majority of our non-WAP species $(>96 \%)$ were wetland species (FACW or OBL). For each year analyzed in the study, the proportion of species cover represented by each of these categories (WAP wetland, WAP upland/adaptive, and Non-WAP wetland) were determined using the following equation:

Category Proportion $_{x}=\Sigma C_{x} / C_{w} \times 100$

where $\sum C_{x}=$ the summation of the cover of all the species within a category, $C_{w}=$ the total coverage, and ${ }_{X}=$ species category (WAP wetland, WAP adaptive/upland, and NonWAP wetland).

Annual contributions to overall cover by each category were determined over a 10-year period (2005-2014) per hydrologic group. These proportions were graphed over time to inspect temporal trends in community composition before and after hydrologic recovery.

Species Importance Percentages To identify dominant species, a species importance percentage was calculated per hydrologic group and period based on a modified method described by Host et al. (1993). Percent cover for each species per wetland was averaged per hydrologic group for both the pre- and post-hydrologic recovery periods. To relativize percent cover, values were divided by the total vegetation cover reported for each hydrologic group during a specific period. Frequency of each species was determined as the proportion of wetlands in which it occurred within each hydrologic group. Using these relative measures, species importance percentages were calculated for all groups during both pre- and post-recovery periods suing the following equation:

Importance Percentage $={ }^{F_{i}} \times C_{i} / T_{C} \times 100$

where, $F_{i}=$ frequency of species $i, C_{i}=$ average cover of species $i$, and $T C=$ sum of all species cover per group.

Species with importance percentages $>5$ were used to identify the most prevalent species in each hydrologic group and to examine changes that occurred between the pre- and postrecovery period.

\section{Results}

\section{Species Richness, Cover and Prevalence Index}

Mean species richness differed significantly between pre- and post-recovery periods $(\mathrm{F}=88.1, \mathrm{df}=1, p<0.01)$, as all three hydrologic groups increased in annual species richness after hydrologic recovery (Fig. 3). Comparing the pre- and postrecovery periods, mean species richness increased from $5.3 \pm$ 1.3 to $12.1 \pm 1.3$ in most-altered wetlands, from $7.4 \pm 0.9$ to 
Table 2 Description of WAP plant species classifications and habitat for cypress dome wetlands and corresponding wetland indicator ratings (per Chapter 62 340, Florida Administrative Code)

\begin{tabular}{|c|c|c|}
\hline $\begin{array}{l}\text { WAP } \\
\text { classification }\end{array}$ & $\begin{array}{l}\text { Wetland indicator } \\
\text { rating(s) }\end{array}$ & Species habitat \\
\hline Upland & UPL & Almost never occur in saturated soils; typically found in uplands \\
\hline Adaptive & $\begin{array}{l}\text { FAC, FACU, } \\
\text { UPL }\end{array}$ & Opportunist or ruderal species that normally occupy mesic or xeric soils \\
\hline Transition & OBL, FACW & $\begin{array}{l}\text { Grow where water saturates or inundates the soil surface, typically tolerate } \\
\text { shallow and shorter hydroperiods }\end{array}$ \\
\hline Outer-Deep & OBL, FACW & $\begin{array}{l}\text { Grow where water saturates or inundates the soil surface, typically tolerate } \\
\text { deeper and longer hydroperiods than transition species }\end{array}$ \\
\hline Deep & OBL, FACW & $\begin{array}{l}\text { Grow where water saturates or inundates the soil surface, tolerate deeper } \\
\text { and longer hydroperiods than outer-deep species }\end{array}$ \\
\hline Non-WAP & OBL to UPL & $\begin{array}{l}\text { Upland and wetland plant species either not typically associated with } \\
\text { cypress domes of west-central Florida or that are not sensitive to hy- } \\
\text { drologic changes }\end{array}$ \\
\hline
\end{tabular}

$15.2 \pm 1.3$ in marginally-altered wetlands, and from $7.9 \pm 1.3$ to $13.5 \pm 2.4$ species in least-altered wetlands (Fig. 4). Compared to other wetland groups, there was also a greater range in species richness detected among the most-altered wetlands in the post-recovery period as indicated by box plots (Fig. 4). This was in contrast to the much narrower range of species richness detected for the least-altered wetlands (Fig. 4). Species richness tests between hydrologic groups were not done because of variation in plot sizes that confounded comparisons but means were similar across groups.

During the pre-recovery period, mean understory cover was similar among hydrologic groups and ranged between
$9.4 \pm 2.2 \%$ (marginally-altered wetlands) and $11.3 \pm 4.4 \%$ (least-altered wetlands). Cover did not shift substantially among groups during the post-recovery period and ranged between $9.3 \pm 1.0 \%$ (marginally-altered wetlands) and 10.9 $\pm 1.0 \%$ (most-altered wetlands). No significant differences or interactions in plant cover were detected between groups or periods.

For mean PI scores, there was a significant interaction between hydrologic group and pre- vs. post-recovery periods $(\mathrm{F}=4.8, \mathrm{df}=2, p<0.01$; see Fig. 4). Before recovery, the most-altered wetlands had significantly higher PI values $(2.3 \pm 0.2)$ than least-altered wetlands (mean $1.8 \pm 0.1)$
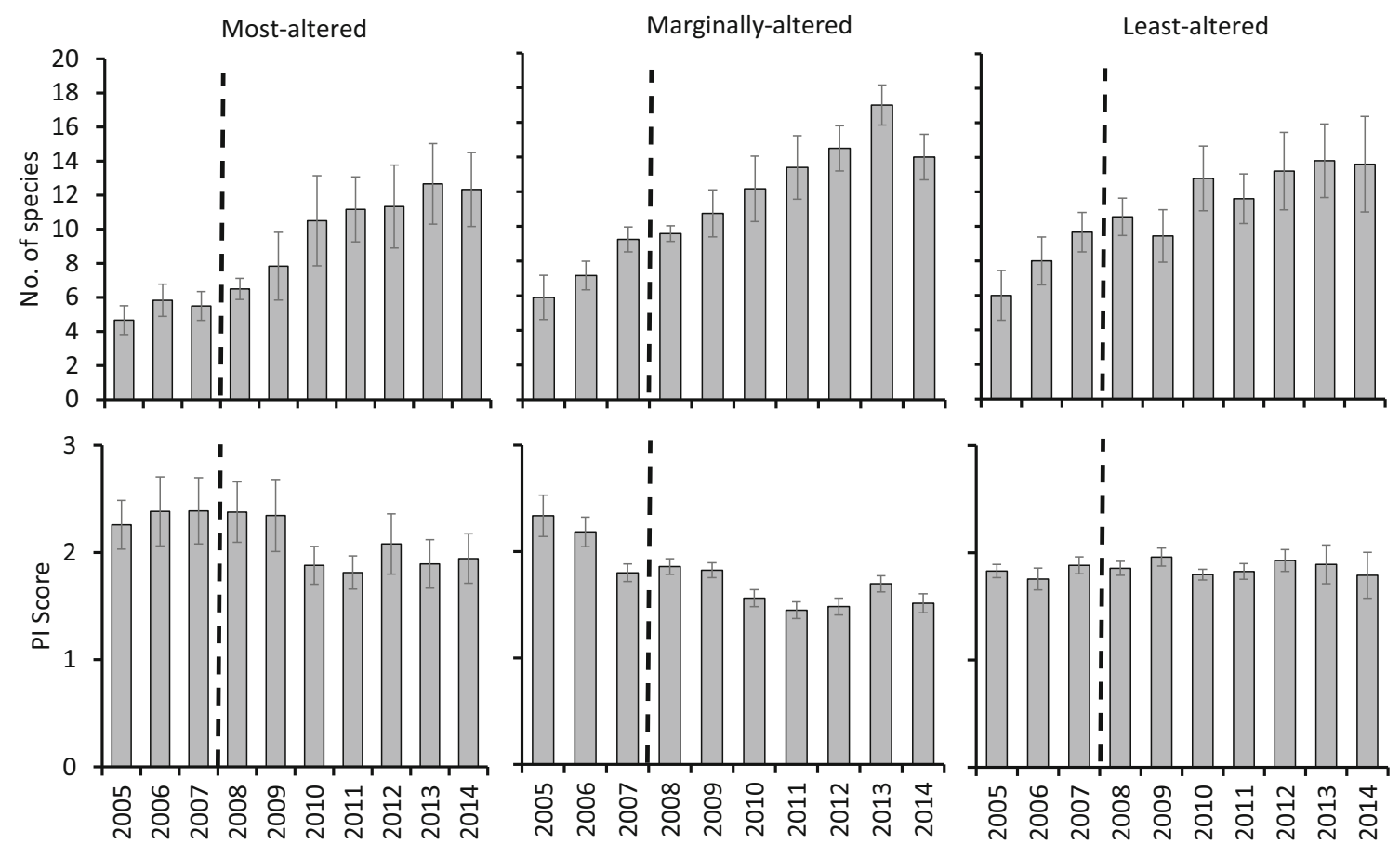

Fig. 3 Mean $( \pm \mathrm{SE})$ annual wetland species richness and prevalence index (PI) for each hydrologic group. Dashed line indicates the initiation of hydrologic recovery 

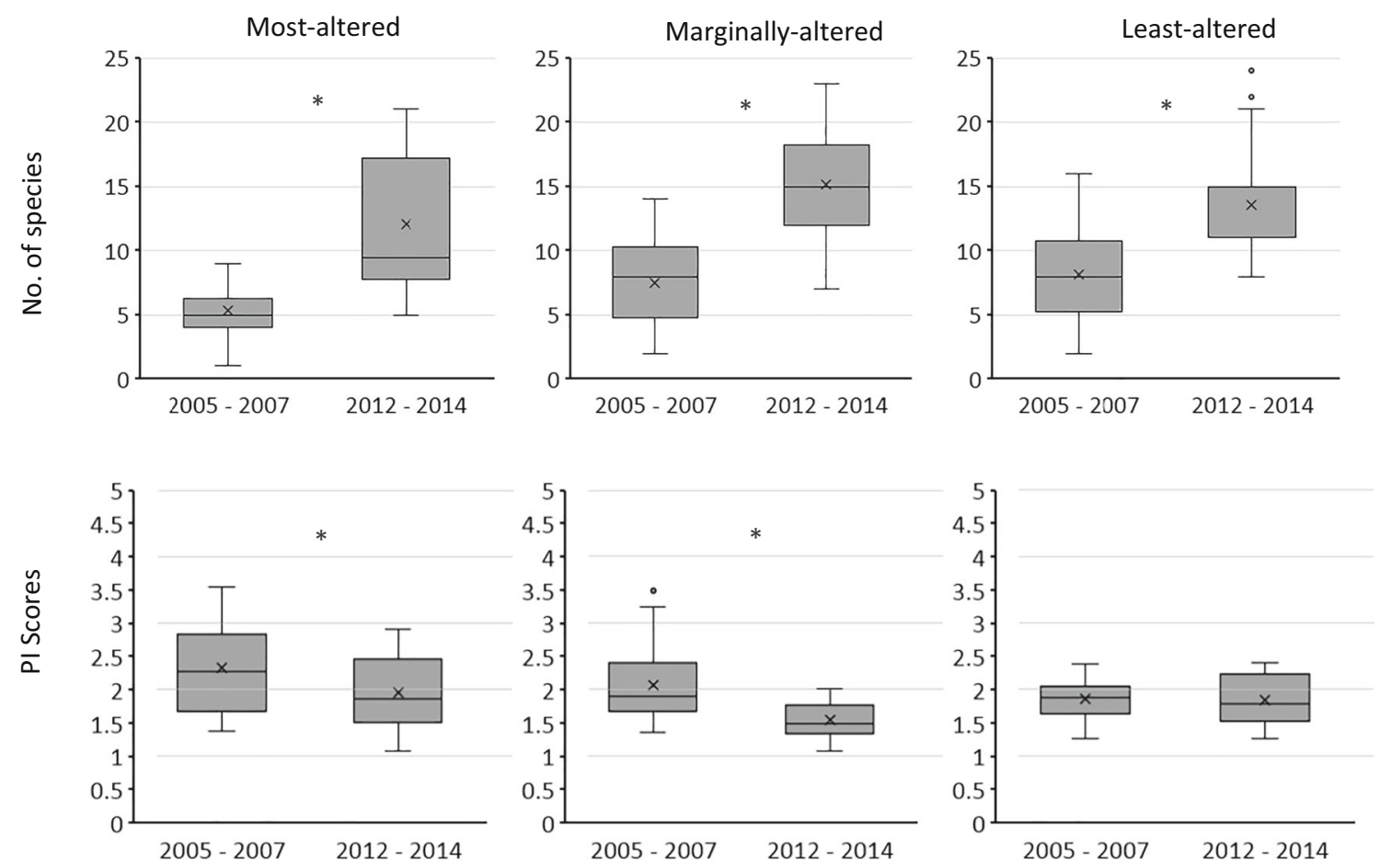

Fig. 4 Box-plot comparison of species richness and prevalence index (PI) for each wetland hydrologic group during pre- and post-hydrologic recovery period. ' $*$ ' indicate significant differences $(p<0.05)$ detected between periods based on pairwise comparison

(Tukey $\mathrm{F}=5.9, \mathrm{df}=1, \mathrm{p}<0.01$ ), with intermediate values $(2.1 \pm 0.1)$ determined for marginally-altered wetlands (Fig. 3). After recovery, mean PI scores decreased significantly to $2.0 \pm 0.1$ in most-altered wetlands and to $1.6 \pm 0.1$ in marginally-altered wetlands, but remained relatively stable (mean $1.9 \pm 0.1$ ) in least-altered wetlands (Fig. 4).

\section{WAP Category Proportions}

During the pre-recovery period, vegetation recorded at all wetlands was largely composed of WAP-listed species (Fig. 5), however most-altered wetlands had a high proportion of upland/adaptive species $(36.3 \pm 3.3 \%)$ and least-altered wetlands had the lowest $(5.6 \pm 1.4 \%)$. Both most- and marginally-altered wetlands showed notable reductions in WAP upland/adaptive cover after hydrologic recovery. Comparing pre- to post-recovery periods, the mean annual proportion of WAP upland/adaptive species cover was reduced from $21.8 \pm 5.4$ to $7.8 \pm 1.7 \%$ for marginally-altered wetlands and $36.3 \pm 3.3$ to $23.7 \pm 1.6 \%$ for most-altered wetlands. All hydrologic groups also experienced an increase in proportion of Non-WAP wetland species following hydrologic recovery. Marginally-altered wetlands had the greatest change, going from $18.7 \pm 3.9 \%$ during the pre-recovery to $50.1 \pm 3.8 \%$ in the post-recovery period. Changes in NonWAP were least substantial in the least-altered wetlands but still increased from $27.5 \pm 1.6$ to $40.4 \pm 4.1 \%$ between preand post-recovery.

\section{Species Importance Percentages and Community Comparisons}

Species importance percentages were used to reveal changes in community composition between the pre- and post-recovery periods in each hydrologic group (Table 3). During the prerecovery period, the wetland grass blue maidencane (Amphicarpum muhlenbergianum) was the most important species in the marginally- and least-altered wetland communities (29.0 and 33.2 importance percentage, respectively) while the upland forbs dog fennel (Eupatorium capillifolium) and Elliott's milkpea (Galactia elliottii) were the most important species in the most-altered wetlands (combined 25.2 importance percentage). Post-recovery, A. muhlenbergianum was still the dominant species in the least-altered wetlands and remained an important species in marginally-altered wetlands. Amphicarpum muhlenbergianum also emerged as an important species in mostaltered wetlands (9.1 importance percentage) (Table 3). NonWAP wetland species also became important in the most- and marginally altered wetlands post-recovery (combined species importance percentage was 18.9 and 19.4, respectively). Virginia chain fern (Woodwardia virginica) was particularly prevalent in both most-and marginally-altered (12.5 and 11.5 importance percentage, respectively). 

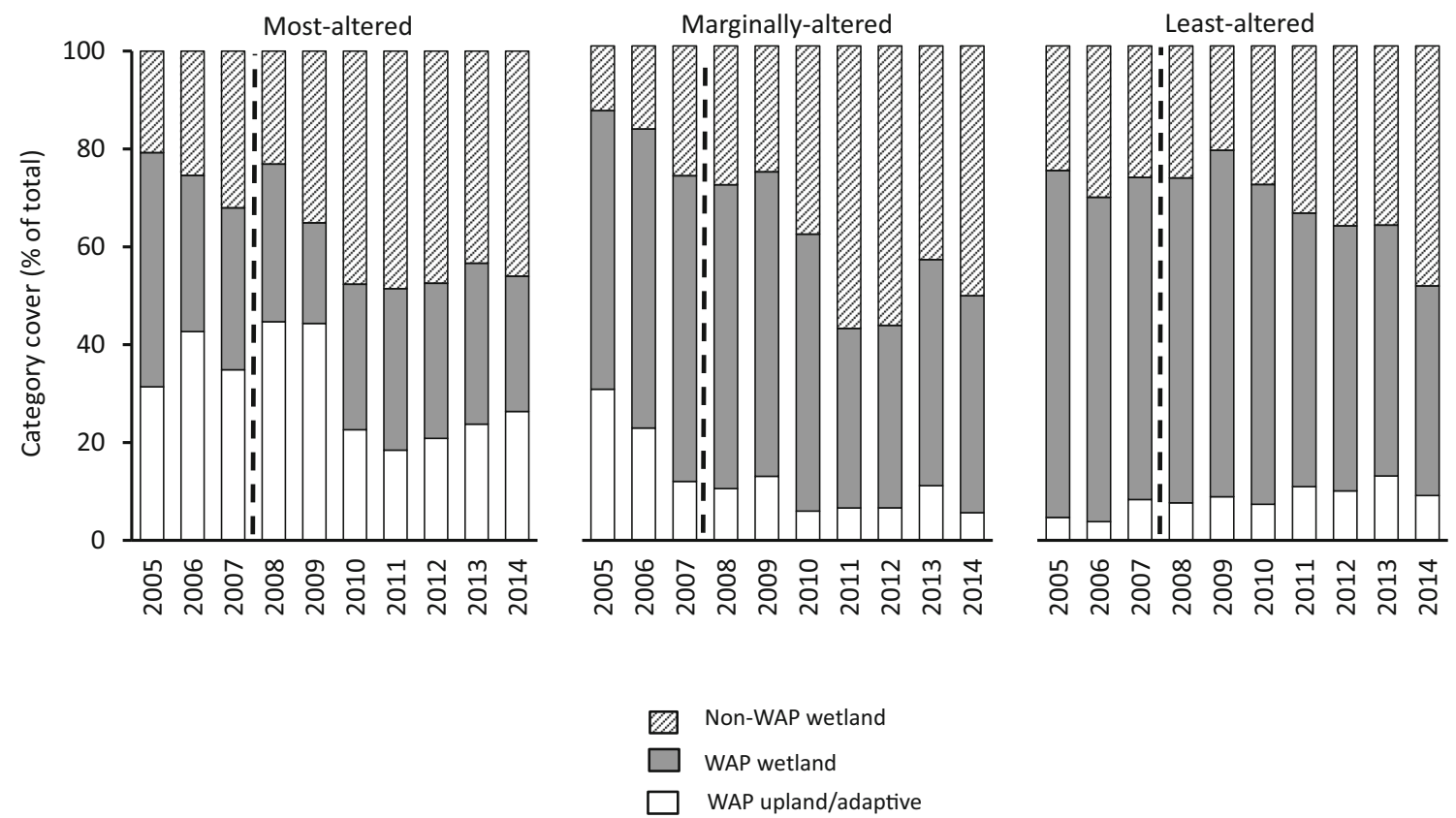

Fig. 5 Average distribution of WAP wetland, WAP upland/adaptive, and non-WAP wetland species in each hydrologic group based on relative percent cover. Dashed line indicates the initiation of hydrologic recovery

\section{Discussion}

Analyses from monitoring data at the SWP showed that there was detectable responses to hydrologic recovery for all wetland groups. For example, PI scores from marginally- and most-altered wetlands decreased to values comparable to least-altered wetlands. This was consistent with noted changes in dominant species per hydrologic group. Prior to hydrologic recovery, important species in most-altered wetlands included FACU plants dog fennel (Eupatorium capillifolium) and
Elliot's milk pea (Galactia elliotti) indicating drier conditions with less inundation. Post recovery, most-altered wetlands retained some FACU species but displayed an overall decrease (25.2 to $9.8 \%$ ) in the importance percentage of nonwetland species and an increase (5.6 to 27.9\%) in important $\mathrm{OBL}$ and FACW wetland species. It was noted that in the prerecovery period, all hydrologic groups had an average PI scores of $\leq 3.0$ indicating that wetland vegetation technically met the hydrophytic criteria for wetland classification before recovery (Reed 1988; USACE 2012). However, for the areas
Table 3 Cumulative importance percentages and national wetland indicator (NWI) rating of dominant species (importance percentage $>5$ ) for each hydrologic group during pre-recovery (2005-07) and post-recovery (2012-14). Omitted values (-) indicate periods where species importance percentage was $<5$. Non-WAP species are indicated in bold

\begin{tabular}{|c|c|c|c|c|}
\hline \multirow[b]{2}{*}{ Hydrologic Group } & \multirow[b]{2}{*}{ Species } & \multirow[b]{2}{*}{ NWI Rating } & \multicolumn{2}{|c|}{ Importance $\%$} \\
\hline & & & $\begin{array}{l}\text { Pre- } \\
\text { recovery }\end{array}$ & $\begin{array}{l}\text { Post- } \\
\text { recovery }\end{array}$ \\
\hline \multirow[t]{6}{*}{ Most-altered } & Eupatorium capillifolium & FACU & 15.27 & - \\
\hline & Galactia elliotti & FACU & 9.89 & 9.79 \\
\hline & Panicum hemitomom & OBL & 5.59 & - \\
\hline & Woodwardia virginica & OBL & - & 12.46 \\
\hline & Amphicarpum muhlenbergianum & FACW & - & 9.07 \\
\hline & Rhynchospora inundata & OBL & - & 6.41 \\
\hline \multirow[t]{4}{*}{ Marginally-altered } & Amphicarpum muhlenbergianum & FACW & 28.97 & 10.84 \\
\hline & Stillingia aquatica & OBL & 5.13 & - \\
\hline & Woodwardia virginica & OBL & - & 11.45 \\
\hline & Carex verrucosa & OBL & - & 7.93 \\
\hline \multirow[t]{3}{*}{ Least-altered } & Amphicarpum muhlenbergianum & FACW & 33.19 & 25.46 \\
\hline & Stillingia aquatica & OBL & 7.08 & - \\
\hline & Hypericum fasciculatum & FACW & 6.94 & - \\
\hline
\end{tabular}


examined in this study, we would expect much lower PI scores $(<2)$ in the outer deep zone where OBL and FACW species should be abundant. The lower mean PI detected for both marginally- and most-altered wetlands has been demonstrated in wetland restoration elsewhere (Meyer et al. 2010) and reflects some measure of vegetation recovery at the SWP.

Certain species clearly responded to hydrologic recovery to become dominant species during the post-recovery period. The fern Woodwardia virginica was unimportant before recovery but became dominant in both marginally- and mostaltered wetlands afterwards (Table 3). Though not a WAPwetland species, this OBL wetland species has been identified as a common to cypress domes (Noble et al. 2004). Its response post-recovery suggests it may be sensitive to hydrologic change and suitable for inclusion on the WAP-wetland species list. The wetland grass Amphicarpum muhlenbergianum was another common species that was dominant in all hydrologic groups during post-recovery but only abundant in the pre-recovery period for least- and marginally-altered wetlands (Table 3). This species is associated with saturated soils that persist throughout part of the year (Sheahan et al. 2011) along with intermediate shallow inundation, shorter seasonal hydroperiods, and greater light penetration (Marios and Ewel 1983; Florida Natural Areas Inventory 2010). Although it is a FACW species, a recent evaluation of wellfield data showed this species frequents less inundated portions of cypress wetlands (Thurman et al. 2018). Its abundance and persistence in the least-altered wetlands may be an indication of the historical pumping, cypress domes with naturally shorter hydroperiods, or a combination of both.

Species richness increased in all hydrologic groups following passive restoration. This is consistent with other studies that showed richness can increase due to the persistence of some less inundation-tolerant species along with the recruitment of more inundation-tolerant species (Battaglia and Collins 2006; De Steven et al. 2010). The comparable response in species richness by least-altered wetlands was somewhat surprising given that post-recovery change in hydrology was minimal. This observation was confounded somewhat by drought conditions that occurred during the pre-recovery period and likely contributed to increased richness in all groups.

Other related factors not directly measured in this study may also contribute to the vegetative response of wetlands following prolonged groundwater pumping. For example, soil subsidence and compaction are documented in some of the most- and marginally-altered sites due to past drying and oxidation of organic soils (Metz 2011). A recent study using a subset of these SWP wetlands indicated that significant differences in soil decomposition rates persist between hydrologic groups (Bartholomew et al. 2019). Lower relative elevations caused by soil decomposition and subsidence may have increased surface inundation and partially explain the recruitment of wetland species. Other more lasting changes have also occurred to wetland sub-surface confining layers that were fractured during pumping, thereby reducing hydroperiod regardless of pumping reductions (Metz 2011). The presence and absence of fire is another important factor known to affect vegetation in these wetlands (Kirkman et al. 2000). Although recent fire exposure was not apparent during wetland site visits, the likelihood of fire extending into the interior of wellfield cypress domes likely increased prior to hydrologic recovery. Other factors, such as increased tree fall and additional light exposure may have also contributed to variations between more and less altered wetlands at the SWP and other wellfields.

Our results indicated important differences between the most-altered wetlands and the other groups remain and the hydrologic recovery at SWP may not have achieved complete restoration of these sites. However, even with complete hydrologic recovery at SWP, it is uncertain if these wetlands would eventually become similar to least-altered wetlands. The stochastic nature of disturbances, inter-annual precipitation, variable wetland hydrology, and community response makes predicting restoration outcomes difficult (Zedler 2000; De Steven et al. 2010; Maron et al. 2012; Moreno-Mateos et al. 2012). In some cases, other important abiotic or biotic changes may preclude pre-impact communities from becoming reestablished (Beisner et al. 2003; Briske et al. 2006). In this study, most-altered wetlands have maintained a relatively stable proportion of adaptive and upland species (Fig. 5) indicative of the wetland edge and transitional zones. Nevertheless, these wetlands are still providing functions characteristic of cypress domes. De Steven and Gramling (2013) cautioned against tying vegetation restoration success only to replicating reference species assemblage and suggested also considering guild-based or other functional measures of vegetation. It was also noted that most-altered wetlands were the smallest wetland group on average. While monitoring plots were established relative to historic normal pools (and should be somewhat comparable in inundation frequency), these wetlands still may have naturally shorter hydroperiods and drier plant assemblages. Wetland responses to restoration efforts (both in timing and ecological trajectory) are difficult to predict, however long term monitoring data such as available at the SWP provides important insights and highlights the value of monitoring for better ecological understanding and management.

Acknowledgements Funding for this project was provided by the Ecosystem Management and Restoration Research Program within the United States Army Corps of Engineers through a cooperative agreement (W912HZ-14-0026). Additional financial support was provided by the Auburn University Center for Environmental Studies at the Urban Rural Interface and the USDA McIntire Stennis forestry program. Tampa Bay Water and the Southwest Florida Water Management District provided site access, technical assistance, and historical environmental data. We particularly thank Chris Shea at Tampa Bay Water for data interpretation and background information. Diane De Steven provided helpful comments on an earlier version of this manuscript. 
Open Access This article is licensed under a Creative Commons Attribution 4.0 International License, which permits use, sharing, adaptation, distribution and reproduction in any medium or format, as long as you give appropriate credit to the original author(s) and the source, provide a link to the Creative Commons licence, and indicate if changes were made. The images or other third party material in this article are included in the article's Creative Commons licence, unless indicated otherwise in a credit line to the material. If material is not included in the article's Creative Commons licence and your intended use is not permitted by statutory regulation or exceeds the permitted use, you will need to obtain permission directly from the copyright holder. To view a copy of this licence, visit http://creativecommons.org/licenses/by/4.0/.

\section{References}

Asefa T, Adams A, Kajtezovic-Blankenship I (2014) A tale of integrated regional water supply planning: meshing socio-economic, policy, governance, and sustainability desires together. Journal of Hydrology 519:2632-2641

Bartholomew MK (2017) Evaluating the functional response of isolated cypress domes to groundwater alteration in west-Central Florida. M.S. Thesis, Auburn University, Auburn

Bartholomew MK, Anderson CJ, Berkowitz J (2019) Soil conditions following hydrologic restoration in cypress dome wetlands. Wetlands. https://oi.org/10.1007/s13157-018-1061-2

Battaglia LL, Collins BS (2006) Linking hydroperiod and vegetation response in Carolina bay wetlands. Plant Ecology 184:173-185

Beisner BE, Haydon DT, Cuddington K (2003) Alternative stable states in ecology. Frontiers in Ecology and the Environment 1:376-382

Bortolotti LE, Vinebrooke RD, Louis VLS (2016) Prairie wetland communities recover at different rates following hydrological restoration. Freshwater Biology 61:1874-1890

Briske DD, Fuhlendorf SD, Smeins FE (2006) A unified framework for assessment and application of ecological thresholds. Rangeland Ecology and Management 59:225-236

Caldwell PV, Vepraskas MJ, Gregory JD, Skaggs RW, Huffman RL (2011) Linking plant ecology and long-term hydrology to improve wetland restoration success. American Society of Agricultural and Biological Engineers 54:2129-2137

Casey WP, Ewel KC (1998) Soil redox potential in small pond cypress swamps after harvesting. Forest Ecology and Management 112: 281-287

Chapin DM, Page DK (2013) Response of delta vegetation to water level changes in a regulated mountain lake, Washington state, USA. Wetlands 33:431-444

De Steven D, Gramling JM (2013) Multiple factors influence the vegetation composition of southeast U.S. wetlands restored in the wetlands reserve program. Journal of the Torrey Botanical Society 140: 453-464

De Steven D, Sharitz RR, Barton CD (2010) Ecological outcomes and evaluation of success in passively restored southeastern depressional wetlands. Wetlands 30:1129-1140

De Steven D, Shartiz RR, Singer JH, Barton CD (2006) Testing a passive revegetation approach for restoring coastal plain depression wetlands. Restoration Ecology 14:452-460

Dierberg FE, Brezonik PL (1984) Water chemistry of a Florida cypress dome. University of Florida Press, Gainesville

Dooris PM, Dooris GM, Rochow TF, Lopez M (1990) The effects on wetland vegetation and habitat value caused by altered hydroperiods resulting from groundwater withdrawals in Central Florida: Brooksville. Southwest Florida Water Management District Environmental Section Technical Report
Erwin K (1991) An evaluations of wetland mitigation in the South Florida water Management District. Volume I. Report to the South Florida Water Management District, West Palm Beach

Florida Natural Areas Inventory (2006) Natural community descriptions to accompany a vegetation map of upper Hillsborough. Unpublished report to the Southwest Florida water Management District. Florida Natural Areas Inventory, Tallahassee

Florida Natural Areas Inventory (2010) Guide to the natural communities of Florida: 2010 Edition. Florida Natural Areas Inventory, Tallahassee

Florida Climate Center data was accessed and downloaded in 2018. This is the website: https://climatecenter.fsu.edu/climate-data-accesstools/downloadable-data

Froend R, Sommer B (2010) Phreatophytic vegetation response to climatic and abstraction-induced groundwater drawdown: examples of long-term spatial and temporal variability in community response. Ecological Engineering 36:1191-1200

Galatowitsch SM, van der Valk AG (1996) The vegetation of restored and natural prairie wetlands. Ecological Applications 6:102-112

Haag KH, Lee TM, Herndon DC (2005) Bathymetry and vegetation in isolated marsh and cypress wetlands in the northern Tampa Bay area, 2000-2004. USGS Scientific Investigations Report, Reston, Virginia

Halle S (2007) Science, art or application - the "karma" or restoration ecology. Restoration Ecology 15:358-361

Host GE, Ramm CW, Padley EA, Pregitzer KS, Hart JB, Cleland DT (1993) Field sampling and data analysis methods for development of ecological and land classifications; an application of the Manistee nation Forest. USDA Forest Service, Washington, DC

Howard RJ, Wells CJ (2009) Plant community establishment following drawdown of a reservoir in southern Arkansas, USA. Wetlands Ecology and Management 17:56-583

Kentula ME (2000) Perspectives on setting success criteria for wetland restoration. Ecological Engineering 15:199-209

Kirkman LK, Goebel PC, West L, Drew MB, Palik BJ (2000) Depressional wetland vegetation types: a question of plant community development. Wetlands 20:373-385

Kirkman LK, Smith LL, Golladay SW (2012) Southeastern depressional wetlands. In: Batzer DP, Baldwin AH (eds) Wetland habitats of North America: ecology and conservation concerns. University of California Press, Berkeley, pp 203-215

Lewis DB, Feit SJ (2015) Connecting carbon and nitrogen storage in rural wetland soil to groundwater abstraction for urban water supply. Global Change Biology 21:1704-1714

Lichvar RW, D.L. Bank, Kirchner WN, Melvin NC (2016) The National Wetland Plant List: 2016. Wetland ratings. Phytoneuron 30:1-17

Lee TM, Haag KH, Metz PA, Slacks LA (2009) The comparative hydrology, water quality, and ecology of selected natural augmented freshwater wetlands in west-Central Florida: U.S. Geological Survey Professional Paper

Marios KC, Ewel KC (1983) Natural and management-related variation in cypress domes. Forest Science 29:627-640

Maron M, Hobbs RJ, Moilanen A, Matthews JW, Christie K, Gardner TA, Keith DA, Lindenmayer DB, McAlpine CA (2012) Faustian bargains? Restoration realities in the context of biodiversity offset policies. Biological Conservation 155:141-148

Matthews JW, Sptrea G, Endress AG (2009) Trajectories of vegetationbased indicators to assess wetland restoration progress. Ecological Applications 19:2093-2107

Metz PA (2011) Factors that influence the hydrologic recovery of wetlands in the Northern Tampa Bay Area, Florida. U.S. Geological Survey Scientific Investigations Report 2011-5127

Meyer CK, Whiles MR, Baer SG (2010) Plant community recovery following restoration in temporally variable riparian wetlands. Restoration Ecology 18:52-64 
Mitsch WJ, Wilson RF (1996) Improving the success of wetland creation and restoration with know-how, time and self-design. Ecological Applications 6:77-83

Monk CD, Brown TW (1965) Ecological consideration of cypress heads in northcentral Florida. American Midland Naturalist 74:126-140

Moreno-Mateos D, Power ME, Comín FA, Yockteng R (2012) Structural and functional loss in restored wetland ecosystems. PLoS Biol 10(1):e1001247

National Research Council (2001) Compensating for wetland losses under the clean water act. National Academy Press, Washington, D.C.

Noble CV, Evans R, McGuire M, Trott K, Davis M, Clairain EJ Jr (2004) A regional guidebook for applying the hydrogeomorphic approach to assessing wetland functions of depressional wetlands in peninsular Florida. U.S. Army Corps of Engineers ERDC/EL TR-04-3

Palanisamy B, Chui TFM (2013) Understanding wetland plant dynamics in response to water table changes through ecohydrological modeling. Ecohydrology 6:287-296

Pittman C, Waite M (2009) Paving paradise: Florida's vanishing wetlands and the failure of no net loss. University Press of Florida, Gainesville

Quinn GP, Keough MJ (2002) Experimental design and data analysis for biologists. Cambridge Press, Cambridge

Reed, PB (1988) National list of plant species that occur in wetlands: 1988 national summary. United States Department of the Interior, Fish and Wildlife Service, Washington, DC, USA. Biological Report 88(24)

Rochow TF (1998) The effects of water table level changes on freshwater marsh and cypress wetlands in the Norther Tampa Bay region: a review: Brooksville. Southwest Florida Water Management District Technical Report 1998-1

Sheahan CM, Grabowski J, Williams MJ (2011) Plant guide for Muhlenberg maidencane (Amphicarpum muehlenbergianum). USDA-NRCS, Brooksville Plant Materials Center, Brooksville
Southwest Florida Water Management District (SWFWMD) and Tampa Bay Water (TBW) (2005) Wetland assessment procedure (WAP) instruction manual for isolated wetlands. Southwest Florida Water Management District and Tampa Bay Water, Tampa, Florida

Southwest Florida Water Management District (2009) Alternative water sources: Accessed January 6, 2016, athttp://www.swfswm.state.fl. us/publications/files/currents_alternative.pdf

Stankey DL (1982) Soil survey of Pasco County, Florida. United States Soil Conservation Service, US Government Print Office

Tampa Bay Water (2009) Consolidated Water Use permit Annual Interpretive Report. Tampa Bay Water, Tampa, FL., USA. (Prepared By GPI Southeast Inc.)

Thurman PE, Crisman TL, Carr D (2018) Utilizing a historical database to refine ground cover vegetation as indicators of wetland hydrology. Wetland Ecology and Management 26:37-48

United States Army Corps of Engineers (USACE) (2012) National Wetland Plant List. Available online at http://rsgisias.crrel.usace. army.mil/NWPL/

van der Valk AG (1981) Succession in wetlands: a Gleasonian approach. Ecology 5:338-349

Wentworth TR, Johnson GP (1986) Use of vegetation in the designation of wetlands. USDI, Fish and Wildlife Service, Division of Contracting and General Services, September

Young GL, Karr BL, Leopold BD, Hodges JD (1995) Effects of Greentree reservoir management on Mississippi bottomland hardwoods. Wildlife Society Bulletin 23:525-531

Zedler J (2000) Progress in wetland restoration ecology. TREE 15:402407

Publisher's Note Springer Nature remains neutral with regard to jurisdictional claims in published maps and institutional affiliations. 